\title{
Erythema Nodosum in Pregnancy
}

\author{
Kholoud A. Ghamri, MD, ABIM, FRCPC, \\ and Kara Nerenberg ${ }^{1}$, MD, FRCPC \\ Department of Obstetrics Medicine Royal Alexandra Hospital, \\ Edmonton, Alberta, Canada \\ Department of Internal Medicine, King Abdulaziz University, \\ Jeddah, Saudi Arabia \\ ${ }^{1}$ Department of Internal Medicine, University of Ottawa, \\ Ottawa, Canada \\ dr_kholoudghamri@hotmail.com
}

\begin{abstract}
Erythema nodosum is a condition characterized by erythematous, tender and nonulcerating nodules (usually in a pretibial location) that can occur during pregnancy. While the pathophysiology often represents late hypersensitivity reaction to antigens associated with infections, certain medications and medical conditions as well as pregnancy itself can be the cause. The following case details a pregnant woman's clinical course and diagnosis of Lofgren's syndrome (triad of erythema nodosum, bilateral hilar adenopathy and polyarthritis).
\end{abstract}

Keywords: Lofgren's syndrome, Sarcoidosis, Erythema nodosum, Pregnancy.

\section{Introduction}

Erythema nodosum (EN) is characterized by red or violet, tender and nonulcerating nodules that usually develop in a pretibial location. EN is presumed to represent late hypersensitivity reaction to antigens

\footnotetext{
$\overline{\text { Correspondence \& reprint request to: }}$

Dr. Kholoud A. Ghamri

Fellow, Obstetric Medicine, Royal Alexandra Hospital 331 Community Service Centre, 10240 Kingsway Avenue Edmonton, Alberta T5H 3V9, Canada
}

Accepted for publication: 26 December 2013. Received: 17 November 2013. 
associated with the various infectious agents, drugs, and other diseases. Importantly, pregnancy itself is a cause of EN. Prompt recognition and diagnosis during pregnancy is important for both maternal and fetal reasons.

\section{Case Report}

A 30-year-old woman G2P1 was seen at 12 weeks gestation in the Obstetric Medicine clinic for a 3-week history of rash, polyarthralgia and ankle swelling. She had a similar episode one year prior lasting 3 months. Her other medical history included Hashimoto's disease and renal stones. On examination, multiple lesions consistent with erythema nodosum were noted on legs and arms (Fig. 1), as well as bilateral ankle effusions (Fig. 2). Lungs were clear. Subsequent skin biopsy results were consistent with erythema nodosum (EN).

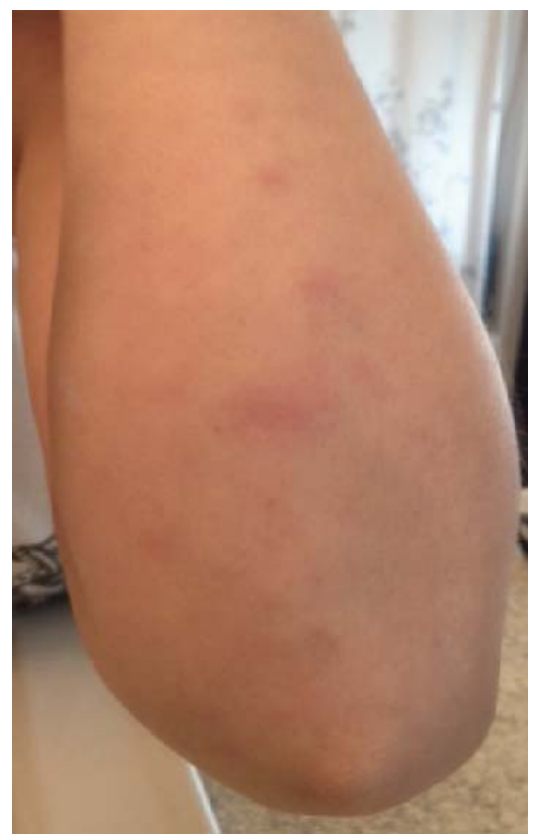

Fig. 1. Erythema nodosum on upper extremity.

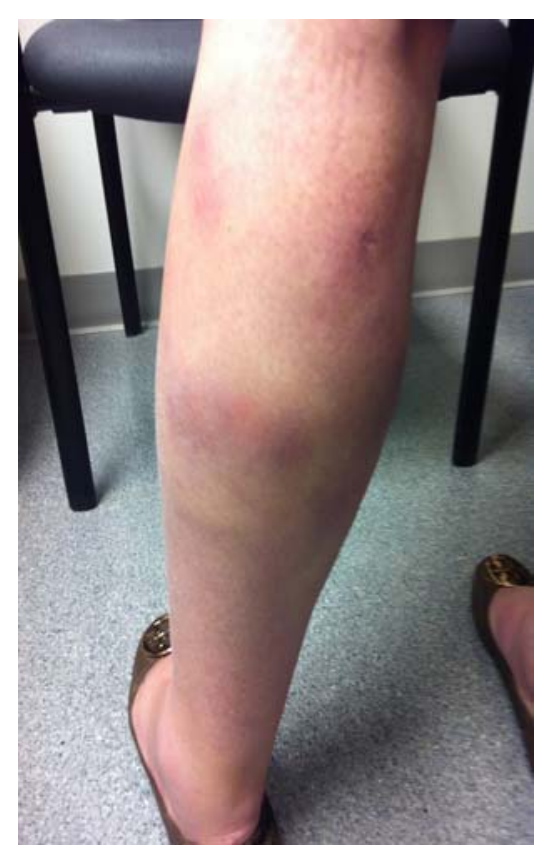

Fig. 2. Erythema nodosum lesions and ankle effusion. 
Clinical recognition of EN is the key in order to determine the underlying cause given the broad differential diagnosis including: Infections, certain medications, sarcoidoisis, inflammatory bowel disease and idiopathic (up to 55\%) ${ }^{[1]}$. Importantly, pregnancy itself is a cause of $\mathrm{EN}^{[2]}$. Although the course of $\mathrm{EN}$ is generally selflimiting, it is essential to find the cause during pregnancy for several reasons: First, to enable initiation of appropriate treatment if required (e.g., Behcet's); second, the underlying condition may affect the pregnancy or delivery recommendations (e.g., sarcoidosis with pulmonary disease); and third, the underlying condition may progress without treatment and adversely affect the woman's health (e.g., tuberculosis and lymphoma) ${ }^{[3]}$.

As such, a work-up on this patient was initiated to determine the etiology of EN: Chest X-ray showed bilateral hilar lymphadenopathy with no evidence of fibrosis. C-reactive protein was elevated at 81.5 $\mathrm{mg} / \mathrm{L}$. Normal calcium level was observed. Auto-immune and infectious tests were unremarkable. The diagnosis was Lofgren's syndrome (triad of EN, bilateral hilar adenopathy and arthritis) secondary to sarcoidosis.

\section{Discussion}

In general, sarcoidosis remains relatively stable in pregnancy, and many women have improvement in their symptoms ${ }^{[3]}$. Key issues in pregnancy relate to underlying maternal lung disease (which may limit fetal growth), hypercalcemia (causing neonatal hypocalcemia), maternal heart block (which may affect delivery), and the use of glucocorticoids (congenital malformations in first trimester and maternal hyperglycemia $)^{[3]}$.

\section{Conclusion}

Erythema nodosum in pregnancy, while relatively uncommon, requires prompt recognition in order to initiate a diagnostic work-up to determine the underlying etiology, which may require treatment in pregnancy in order to optimize the health of the mother and the fetus. 


\section{References}

[1] Schwartz RA, Nervi SJ. Erythema nodosum: A sign of systemic disease. Am Fam Physician 2007: 75(5): 695-700.

[2] Mert A, Kumbasar H, Ozaras R, Erten S, Tasli L, Tabak F, Ozturk R. Erythema nodosum: an evaluation of 100 cases. Clin Exp Rheumatol 2007; 25(4): 563-570.

[3] Euliano TY, White SE, Aleixo L. Sarcoidosis in a pregnant woman. $J$ Clin Anesth 1997; 9(1): 78-86. 


\section{التهاب الجلد العقدي في الحمل}

\section{خلود علوي غمري، وكارا نرنبرج'}

$$
\begin{aligned}
& \text { قسم الباطنة تخصص باطنة في النساء الحوله، }
\end{aligned}
$$

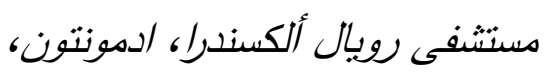

$$
\begin{aligned}
& \text { ألبرتا - كندا } \\
& \text { جلة - المدلكة العربية السعودية } \\
& \text { 'قسم الطب الباطني، جامعة أوتاوا، أوتاوا - كندا }
\end{aligned}
$$

المستخلص. التهاب الجلد العقدي يتميز بعقد حساسة حمراء إلي بنفسجية اللون وغالبا ما يظهر حول قصبة الساق الأكبر . يعتقد أنها نتيجة تحسس منأخر لمولد المضاد الناتج عن التهابات

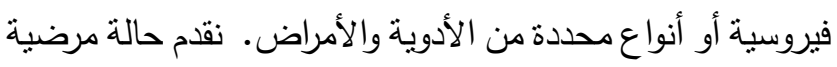

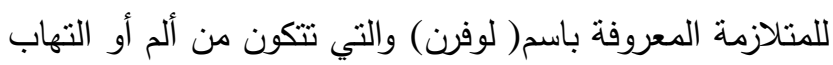
في المفاصل، التهاب الجلد العقدي وتضخم في الغدد اللمفاوية الصدرية التي تم تشخيصها خلال فترة الحمل. 